\title{
Comparison of DAC-ELISA and Tissue Blot Immunoassay for the Detection of Acidovorax avenae subsp. avenae, causal agent of Red Stripe of Sugarcane
}

\author{
Syed Zia-UI-Hussnain ${ }^{1 *}$, C. A. Rauf ${ }^{1}$, M. I. Haque ${ }^{1}$, Shahid Afghan², Tariq Mukhtar ${ }^{1}$, Farah Naz ${ }^{1}$, M. Kausar Nawaz Shah ${ }^{3}$ and Aamir Shahazad
}

${ }^{1}$ Department of Plant Pathology, Pir Mehr Ali Shah (PMAS) Arid Agriculture, University, Rawalpindi, Pakistan

${ }^{2}$ Shakarganj Sugar Research Institute, Toba Road Jhang, Pakistan

${ }^{3}$ Department of Plant Breeding and Genetics, Pir Mehr Ali Shah (PMAS) Arid Agriculture University, Rawalpindi, Pakistan

\begin{abstract}
Direct Antibody Coating Enzyme Linked Immunoassay (DAC-ELISA) and Tissue Blot Immunoassay (TBIA) were compared for detection of Acidovorax avenae subsp. avenae (Aaa) in sugarcane samples surveyed in 2010 and 2011. A total of 27 sugarcane clones contained two samples of symptomatic plants, which were tested simultaneously by both serological tests. The results obtained from DAC-ELISA tests showed that 11 of 27 tested samples of sugarcane clones were infected with $A a a$ and 16 were bacteria free; whereas, in duplicate samples only 7 samples were positive for Aaa using the TBIA. The TBIA membranes showed dark blue stain colour in the 7 positive and 20 were negative. It was concluded that the DAC-ELISA had false positives in the 4 clones (SPF-238, CP77-400, SPF-213 and GT-11) that were negative using TBIA. Assay time was also minimized in performing TBIA test as equivalence to DAC-ELISA. Related to the test performing time at least 25-30 hours were consumed for the completion of DAC-ELISA assay, while only 6-9 hours was required for TBIA assay with reliable results. Both assays gave Aaa positive for clones HoSG-315, CPSG-437, NSG-49, CPSG-2453, CP-NIA-82-223, CSSG-2402 and US-114. TBIA tests were distinct with clear positive and negative results having minimum diagnostic error. On the other hand quantitative assay of bacteria is a significant feature of DAC-ELISA but low optical density readings above background were inconsistent with the TBIA and were considered false positive results. Amongst the variety of immunological tests available in Pakistan, tissue blot immunoassay (TBIA) is most useful in detecting latent infections in the plant materials.
\end{abstract}

Keywords: Sugarcane; Varieties; DAC-ELISA; TBIA; Symptomatic plants

\section{Introduction}

Sugarcane (a complex hybrid of Saccharum spp.) is the oldest energy source (sucrose) for human beings and more recently a source of fuel for motor vehicles. It is a high value cash crop and plays vital role in the enhancement of socio-economic conditions of farming community as well as in industry and trade. It's by-products, molasses and bagasse, are the cheapest source of feed stock for animals and industries [1].

Pakistan ranks fifth in area of sugarcane production in the world with 1.00 million hectares of area. Average cane yield in Pakistan is 50 tons/ha and sugar recovery is $8.0-8.6 \%$, which are lower than the world average of 63 tons/ha and $10.6 \%$, respectively [2]. Per capita demand of sugar in Pakistan is the $25 \mathrm{~kg}$ per annum [3]. Low sugarcane yields are mainly attributed to different biotic and abiotic factors: insect pests, diseases caused by different pathogens (fungal, bacterial, viral and nematodes), poor nutrition and management, salinity, frost, unfavorable environmental conditions and low yielding varieties.

Pathological problems alone are responsible for colossal losses in production, $15-20 \%$ under ordinary and more than $50 \%$ under severe conditions. Losses of $15-20 \%$ due to diseases are common, sometimes complete crop failure occurs [4]. Red stripe disease has emerged as a serious bacterial disease in sugarcane, infecting commercial varieties and promising clones showing stalk rot symptoms [5]. Red stripe is particularly a problem when the pathogen invades the stalk where it can cause high yield losses. When the pathogen is only present in leaf tissue the disease is minor. The pathogen associated with red stripe of sugarcane also infects oats [6], corn [7] and rice [8].

Red stripe was first observed on sugarcane in Hawaii [9]. The bacterial pathogen was identified as Pseudomonas rubrilineans; now named Acidovorax avenae ssp. avenae (Aaa). Bacterium is gram negative, rod 0.4-0.6 $\mu \mathrm{m} \times 0.8-1.6 \mu \mathrm{m}$. The pathogen is now established and reported from 50 sugarcane growing countries of the world [10] and is present in several locations in Pakistan [11].

The disease is initially characterized by the appearance of green stripes near the midrib that later on turn reddish to dark red stripes. The stripes initially develop at the base of the leaves in June and July in Pakistan. Symptoms spread quickly to more leaves. Disease development is favored by high doses of nitrogen application, high temperature and humidity [12].

The pathogen was initially identified on the basis of symptomatology, growth behavior of the bacterium, grown out test and morphological characteristic under light microscope. These methods of identification were uneconomical, laborious, time consuming and non specific. The pathogen was specifically identified by serological methods mainly ELISA. Electron microscopy and PCR were also employed, which have been hardly attempted in Pakistan.

Because of the spread and potential yield losses of red stripe in Pakistan, an accurate and sensitive diagnostic method(s) are required

*Corresponding author: Syed Zia-Ul-Hussnain, Department of Plant Pathology, Pir Mehr Ali Shah (PMAS) Arid Agriculture, University, Rawalpindi, Pakistan, E-mail: zia.hussnain@shakarganj.com.pk

Received March 14, 2013; Accepted April 23, 2013; Published Apil 28, 2013

Citation: Zia-Ul-Hussnain S, Rauf CA, Haque MI, Afghan S, Mukhtar T, et al. (2013) Comparison of DAC-ELISA and Tissue Blot Immunoassay for the Detection of Acidovorax avenae subsp. avenae, causal agent of Red Stripe of Sugarcane J Plant Pathol Microb 4: 172 doi:10.4172/2157-7471.1000172

Copyright: (c) 2013 Zia-Ul-Hussnain S, et al. This is an open-access article distributed under the terms of the Creative Commons Attribution License, which permits unrestricted use, distribution, and reproduction in any medium, provided the original author and source are credited. 
to identify bacterial free planting material at the early stage. Thus, a stalk diagnostic assay procedure is required guarantee disease-free seed cane. The objective of the study to specifically confirm the identity of the pathogen through antigen-antibody reaction through tissue blot immunoassay (TBIA) and direct antibody coating enzyme linked immunoassay (DAC-ELISA) for the identification of resistance source to be used in Integrated Disease Management (IDM).

\section{Materials and Methods}

\section{Antisera}

Acidovorax avenae subsp. avenae was isolated from highly susceptible sugarcane variety CSSG-2402 on Yeast extract Dextrose Chalk-agar (YDC) medium. Bacterium was grown in $150 \mathrm{~mL}$ YDC broth in $350 \mathrm{ml}$ flasks. Bacterial culture was centrifuged at 10,000 rpm for 30 minutes at $4^{\circ} \mathrm{C}$. Supernatant was discarded and pellets were washed twice with $100 \mathrm{ml}$ membrane filtered sterilized saline $(0.85 \%)$.

Concentrated suspension was prepared using spectrophotometer to get $10^{9} \mathrm{cell} / \mathrm{ml}$ at $600 \mathrm{~nm}$. The suspension was steamed for one hour to get somatic antigen in sonicator (yamato bran sonic-12 ultrasonic cleaner, US PATENT NO 3, 6.81, 6.26) and then cooled down. One ml specific antigen of Aaa was injected intravenously into albino rabbit 6-12 months old. Five such injections were given at weekly interval. Test bleed of rabbit was taken using bleeding rack and obtain approximately $1 \mathrm{ml}$ blood from the ear after one week of the last injection. Blood was relocated into a sterile screw-cap test tube of $50-\mathrm{ml}$ capacity and allowed to clot at room temperature for 2 hours. The clot was separated from the wall of tube using sterilized glass. The serum was kept overnight at 4s. Bacterial culture was centrifuged at $10,000 \mathrm{rpm}$ for 30 minutes at $4^{\circ} \mathrm{C}$. Purification was done by centrifugation at $5000 \mathrm{rpm}$ for $10 \mathrm{~min}$. Merthiolate was added in the antiserum and kept in refrigerator at $4 \mathrm{~s}$. Bacterial culture was centrifuged at $10,000 \mathrm{rpm}$ for 30 minutes at $4^{\circ} \mathrm{C}$.

The antiserum titer was determined by agglutinations in microtitre trays. The first bleed (approximately $10 \mathrm{ml}$ ) was taken at two weeks after the last injection and antiserum titer was determined [13]. Preparation of antigen and antiserum against Aaa was completed for the first time at National Institute for Biotechnology and Genetic Engineering (NIBGE) Faisalabad, Pakistan. The second antibody used in the TBIA and DACELISA tests were goat anti-rabbit IgG-alkaline phosphatase conjugate (Sigma-USA).

\section{Plant materials}

The sugarcane producing areas of Punjab Province, Pakistan including Jhang and Faisalabad regions were surveyed in 2010 and 2011. Samples (i.e., one stalk of each clone) were obtained from mature plants 9-10 month old of sugarcane varieties: HoSG-315, CPSG-437, NSG555, SPF-238, CP77-400, SPSG-79, CPF-237, HSF-240, SPF-213, CSSG668, CSSG-676, NSG-311, GT-11, CPSG-3481, NSG-59, CPSG-2923, CSSG-212, CPSG-104, HoSG-1257, CPSG-25, CSSG-239, CPSG-2713, NSG-49, CPSG-2453, US-114 and CP-NIA-82-223 showing naturally infected diseased symptoms of red stripe [11]. Sugarcane variety CSSG2402 was used as standard check because of its susceptibility to the red stripe of sugarcane. All samples were collected in polyethylene bags and stored in a refrigerator at $4 \mathrm{~s}$. Bacterial culture was centrifuged at 10,000 rpm for 30 minutes at $4^{\circ} \mathrm{C}$ until processed. All collected stalk samples were tested by two different serological assays TBIA and DAC-ELISA.

Detection of Acidovorax avenae subsp. avenae (Aaa) by direct antibody coating enzyme linked immunoassay (DAC-ELISA)

Vascular sap of infected samples was used as antigen. Stalk sections were centrifuged at $8500 \mathrm{rpm}$ for 10 minutes to collect vascular sap. One hundred $\mu \mathrm{l}$ of vascular sap were loaded into wells of microtitter assay plate. Positive control well had $50 \mu$ of cultured Aaa cells of unknown titer. Negative control well had uninfected xylem sap sample. ELISA plate was incubated overnight at $4^{\circ} \mathrm{C}$ in a refrigerator. Wash the sample wells with $150 \mu$ PBST buffer 3 times for 3 minutes each. 100 $\mu \mathrm{l}$ of primary antibody at 1:1000 was loaded in each well of the ELISA plate [14] and incubated at $37^{\circ} \mathrm{C}$ for $2-3$ hours. Then, the plates were washed with washing buffer 3 times with 3 minutes interval. Conjugate (Goat anti-rabbit immunogloblin IgG with alkaline phosphatase (ALP) enzyme) $100 \mu$ was loaded in each well of the ELISA plate. The plates were incubated at $37^{\circ} \mathrm{C}$ for $2-3$ hours. $5 \mathrm{mg} \mathrm{p}$ - nitrophenyl phosphate diluted, in $10 \mathrm{ml}$ of substrate buffer. $150 \mu \mathrm{l}$ of substrate buffer was loaded in each well of the ELISA plate. Results were observed visually for half an hour at room temperature. Later absorbance was also determined spectrophotometrically at $405 \mathrm{~nm}$ in an ELISA reader (ASYS Hitech GmbH. Model. Expert Plus. Type. G020150 [15]. A cut off/threshold $\mathrm{OD}_{405}$ (Optical density) of 0.066 was calculated to indicate the presence of Aaa [16].

\section{Detection of Acidovorax avenae subsp. avenae (Aaa) by tissue blot immunoassay (TBIA)}

The tissue blot immunoassay (TBIA) procedures were performed for detecting the red stripe disease pathogen of sugarcane. $1 \mathrm{~cm}$ core of tissue from each internode was cut in 1-cm lengths and the cut end was placed on a nitrocellulose membrane having $2-\mathrm{cm}$ diameter and centrifuged at $1,700 \mathrm{rpm}$ for $15 \mathrm{~min}$. Membranes were blocked with blocking solution (Tris buffer saline $100 \mathrm{ml}$ and dried milk powder $2 \mathrm{~g}$ ) and incubated for one hour at room temperature. After washing for 1 min in $75 \mathrm{ml}$ Tris buffered saline (TBS), each membrane was immersed in $10 \mathrm{ml}$ primary antibody solution. Incubated and washed 3 times for 5 min in $75 \mathrm{ml}$ TBS. Each membrane (single layer) was exposed with $10 \mathrm{ml}$ anti-rabbit antibody diluted solution and Incubated for 1 hour. Washed 2 times for $15 \mathrm{~min}$ in $75 \mathrm{ml}$ TBS. Immersed membranes in working substrate (Tris-24 g,Napthol-AS-phosphate-3 g, Dimethylformamide-5 $\mathrm{ml}$ and distilled water- $1000 \mathrm{ml}$ ) with $0.075 \mathrm{~g}$ of fast blue and $0.375 \mathrm{ml}$ of $\mathrm{MgCl}_{2}$ (in $75 \mathrm{ml}$ working substrate) in dark for 15-30 min. Membranes were washed and treated with $20 \%$ bleach solution for 20 minutes to remove brownish discoloration. After washing and drying, color of stained/processed nitrocellulose membranes were visually observed [15].

\section{Results and Discussions}

\section{Evaluation by DAC-ELISA}

A total of 27 samples of sugarcane varieties were collected from the field surveys during 2010-2011. A summary of the results of the samples tested with DAC-ELISA is shown in table 1. In DAC-ELISA, $A a a$ was detected from the infected or suspected to be infected samples showing positive reactions (yellow color) of the bacterium (Figure 1). Results showed that two representatives, US-114 and CSSG-2402 have the higher bacterial optical density values (1.379 and 1.390 respectively) were detected and showed highly positive reaction by DAC-ELISA. Five sugarcane varieties HoSG-315 (0.560), CPSG-437 (0.555), NSG49 (0.564), CPSG-2453 (0.556) and CP-NIA-82-223 (0.564) had higher level of absorbance values were positive in the ELISA plate wells [14]. From the representative stalks of 04 varieties like CP77-400, SPF-238, SPF-213 and GT-11 had moderate level of the values (0.101, 0.099, 0.098 and 0.104 ) respectively, showed the light yellow color (Positive reaction). All of the remaining 16 representative were showed negative reaction by the DAC-ELISA test $[17,18]$. 
Citation: Zia-UI-Hussnain S, Rauf CA, Haque MI, Afghan S, Mukhtar T, et al. (2013) Comparison of DAC-ELISA and Tissue Blot Immunoassay for the Detection of Acidovorax avenae subsp. avenae, causal agent of Red Stripe of Sugarcane. J Plant Pathol Microb 4: 172 doi:10.4172/21577471.1000172

\begin{tabular}{|l|l|l|l|l|l|l|l|}
\hline $\begin{array}{l}\text { Sr. } \\
\text { No. }\end{array}$ & Varieties & $\begin{array}{l}\text { Visible } \\
\text { reaction }\end{array}$ & $\left.\mathbf{( O D}_{405} \mathbf{n m}\right)$ & $\begin{array}{l}\text { Sr. } \\
\text { No. }\end{array}$ & Varieties & $\begin{array}{l}\text { Visible } \\
\text { reaction }\end{array}$ & $\mathbf{( O D}_{405} \mathbf{n m}$ \\
\hline 1 & NSG-555 & - & 0.091 & 17 & CP77-400 & + & 0.101 \\
\hline 2 & SPSG-79 & - & 0.090 & 18 & SPF-238 & + & 0.099 \\
\hline 3 & CPF-237 & - & 0.093 & 19 & SPF-213 & + & 0.098 \\
\hline 4 & CSSG-212 & - & 0.095 & 20 & GT-11 & + & 0.104 \\
\hline 5 & HSF-240 & - & 0.090 & 21 & HoSG-315 & ++ & 0.560 \\
\hline 6 & CSSG-668 & - & 0.089 & 22 & CPSG-437 & ++ & 0.555 \\
\hline 7 & CSSG-676 & - & 0.092 & 23 & NSG-49 & ++ & 0.564 \\
\hline 8 & NSG-311 & - & 0.090 & 24 & CPSG-2453 & ++ & 0.556 \\
\hline 9 & CPSG-3481 & - & 0.090 & 25 & $\begin{array}{l}\text { CP- } \\
\text { NIA-82-223 }\end{array}$ & ++ & 0.564 \\
\hline 10 & NSG-59 & - & 0.091 & 26 & US-114 & +++ & 1.379 \\
\hline 11 & CPSG-2923 & - & 0.095 & 27 & CSSG-2402 & +++ & 1.390 \\
\hline 12 & CPSG-104 & - & 0.091 & 28 & + ve control & ++ & 0.561 \\
\hline 13 & HOSG-1257 & - & 0.094 & 29 & -ve control & - & 0.003 \\
\hline 14 & CPSG-25 & - & 0.090 & 30 & $\begin{array}{l}\text { Extraction } \\
\text { buffer }\end{array}$ & - & 0.004 \\
\hline 15 & CSSG-239 & - & 0.091 & 31 & $\begin{array}{l}\text { Threshold } \\
\text { (OD }\end{array}$ & - & 0.066 \\
\hline 16 & CPSG-2713 & - & 0.093 & & & & \\
\hline
\end{tabular}

Table 1: Visual and serological (DAC-ELISA) determination of Aaa.

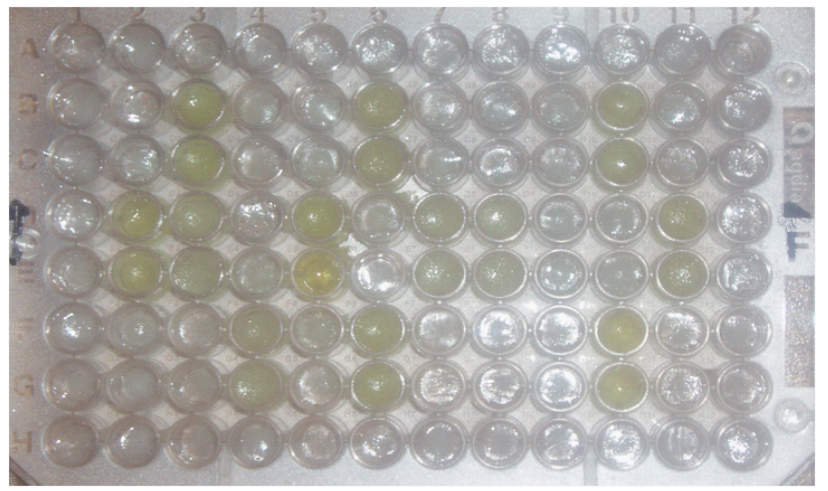

Figure 1: ELISA plate showing positive reactions (Yellow color) against Aaa.

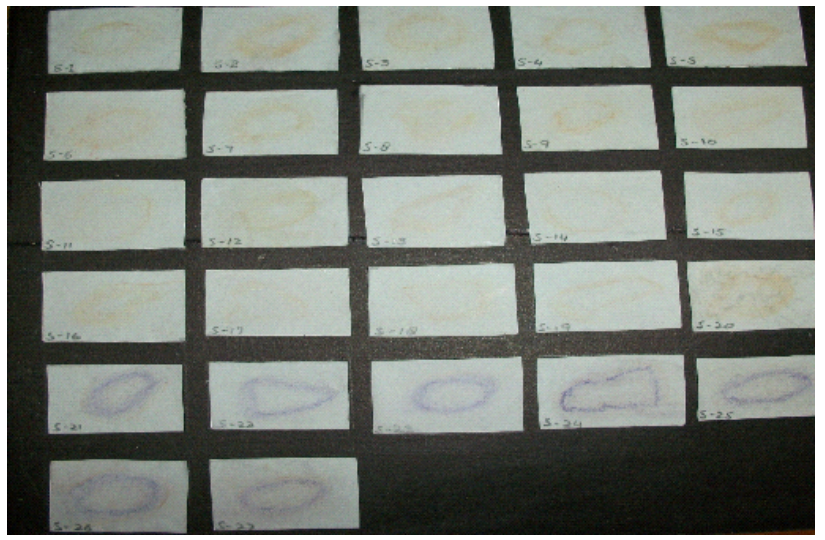

Figure 2: Nitrocellulose membrane showing positive reactions (Dark blue color) against $A$ aa received from symptomatic and suspected to be infected stalks in TBIA Test.

\section{Detection of Acidovorax avenae subsp. avenae (Aaa) by TBIA}

Tests were made by making blots of Aaa infected or suspected to be infected tissue on nitrocellulose membranes using standard procedures [15]. Of the twenty seven promising clones of sugarcane, only seven clones like HoSG-315, CPSG-437, NSG-49, CPSG-2453, CP-NIA-82-223, CSSG-2402 and US-114 were positive for Aaa using TBIA and showed dark blue stain colour where the vascular bundles were imprinted on the nitrocellulose membranes (Figure 2). Representative samples of twenty clones were negative by TBIA and no colour appearance was observed on the membranes $[15,19]$.

\section{Comparison between DAC-ELISA and TBIA}

Both serological tests were performed on duplicate samples of the 27 sugarcane clones. According to the results of the tests, Aaa was not detected in 16 clones viz: NSG-555, SPSG- 79, CPF-237, HSF-240, CSSG-668, CSSG-676, NSG-311, CPSG-3481, NSG-59, CPSG-2923, CSSG-212, CPSG-104, HoSG-1257, CPSG-25, CSSG-239 and CPSG2713 using both DCA-ELISA and TBIA tests. DAC-ELISA showed false positive due to low optical density readings above background were inconsistent results in the 4 clones (SPF-238, CP77-400, SPF-213 and GT-11) based on slight yellow coloration in its test [20]. While, in sugarcane samples viz: HoSG-315, CPSG-437, NSG-49, CPSG2453, CP-NIA-82-223, CSSG-2402 and US-114 were showed positive detection of Acidovorax avenae subsp. Avenae, by both serological tests [15]. In DAC-ELISA test highly positive values were noted from the samples of CSSG-2402 and US-114 but in TBIA test positive reaction was observed of both clones (Table 2).

As per results, TBIA test was used to confirm results positive or negative. In DAC-ELISA test because of the vascular coloration corresponds to where Aaa is located. Since clones (SPF-238, CP77-400, SPF-213 \& GT-11) did not test positive using TBIA the DAC-ELISA results are considered false [21].

Among 27 randomly collected sugarcane samples, TBIA showed $26 \%$ positive and $74 \%$ negative result. On the other hand DAC-ELISA was showed $41 \%$ positive $(36 \%$ false $+64 \%$ true) and $59 \%$ negative results, when compared with TBIA test. Assay time was also minimized in performing TBIA test as equivalence to DAC-ELISA. Related to the test performing time at least 25-30 hours were consumed for the completion of DAC-ELISA assay, while only 6-9 hours was required for TBIA assay with reliable results [22,23].

diagnostic tests have made a significant contribution in diseases control and eradication. Among the variety of immunological tests, TBIA proved to be extremely helpful for large scale testing at a very low cost without much compromise on sensitivity or specificity [14].

\begin{tabular}{|l|l|l|l|l|l|l|l|}
\hline Sample & Varieties & $\begin{array}{l}\text { DAC- } \\
\text { ELISA }\end{array}$ & TBIA & Sample & Varieties & $\begin{array}{l}\text { DAC- } \\
\text { ELISA }\end{array}$ & TBIA \\
\hline S-1 & NSG-555 & - & - & S-15 & CSSG-239 & - & - \\
\hline S-2 & SPSG-79 & - & - & S-16 & CPSG-2713 & - & - \\
\hline S-3 & CPF-237 & - & - & S-17 & CP77-400 & f & - \\
\hline S-4 & CSSG-212 & - & - & S-18 & SPF-238 & f & - \\
\hline S-5 & HSF-240 & - & - & S-19 & SPF-213 & f & - \\
\hline S-6 & CSSG-668 & - & - & S-20 & GT-11 & f & - \\
\hline S-7 & CSSG-676 & - & - & S-21 & HoSG-315 & + & + \\
\hline S-8 & NSG-311 & - & - & S-22 & CPSG-437 & + & + \\
\hline S-9 & CPSG-3481 & - & - & S-23 & NSG-49 & + & + \\
\hline S-10 & NSG-59 & - & - & S-24 & CPSG-2453 & + & + \\
\hline S-11 & CPSG-2923 & - & - & S-25 & CPNIA82-223 & + & + \\
\hline S-12 & CPSG-104 & - & - & S-26 & US-114 & h & + \\
\hline S-13 & HOSG-1257 & - & - & S-27 & CSSG-2402 & h & + \\
\hline S-14 & CPSG-25 & - & - & & & & \\
\hline
\end{tabular}

-= true negative, $+=$ true positive, $\mathrm{f}=$ false positive, $\mathrm{h}=$ highly positive

Table 2: Comparison of observation between TBIA and DAC-ELISA. 
Citation: Zia-UI-Hussnain S, Rauf CA, Haque MI, Afghan S, Mukhtar T, et al. (2013) Comparison of DAC-ELISA and Tissue Blot Immunoassay for the Detection of Acidovorax avenae subsp. avenae, causal agent of Red Stripe of Sugarcane. J Plant Pathol Microb 4: 172 doi:10.4172/21577471.1000172

It is an essential test to be used in developing countries where hi-tech laboratories for diagnoses of the pathogens are not available and cost per sample is a limiting factor for any assay to be adopted for large scale testing $[15,19]$.

\section{Acknowledgments}

The author is grateful to Dr. Shahid Mansoor, Head Plant Biotechnology Division, NIBGE Faisalabad, Pakistan for providing the facilities for the preparation of antisera. I owe my respectful thanks to Dr. Jack C. Comstock, Research Leader ARS USDA, Canal Point Florida, USA for providing the nitrocellulose membranes and valuable guidance for TBIA test.

\section{References}

1. Munir MA, Sarwar MA, Hussain F, Chattha AA (2009) Yield and quality comparison of promising varieties of Autumn sown sugarcane. Pakistan Sugar J 24: 05-08.

2. Zafar M, Ahmad S, Munir MA, Guffar A, Bashir S, et al. (2012) Adaptability study of exotic sugarcane clones under faisalabad agro-climatic conditions. Pakistan Sugar J 27: 11

3. Bahadar K, Quddoos A, Rashid M (2012) Cane yield and sugar potential of sugarcane promising genotypes under the agro-climatic condition of bannu NWFP. Pakistan Sugar J 27: 18-20.

4. Martin JP, Wismer CA (1989) Red Stripe. Diseases of sugarcane major diseases. Elsevier, NY, Tokyo.

5. Hussnain SZ, Haque MI, Mughal SM, Shah KN, Irfan A, et al. (2011) Isolation and biochemical characterizations of the bacteria (Acidovorax avenae subsp. avenae) associated with red stripe of sugarcane. Afr J Biotechnol 10: 71917197.

6. Manns TF (1909) The blade blight of oats-a bacterial disease. Ohio Agric Exp Stn Bull, 91-167.

7. Sumner DR, Schaad NW (1977) Epidemiology and control of bacterial leaf blight of corn (Pseudomonas avenae). Phytopathol 67: 1113-1118.

8. Kadota $L$ (1996) Studies on the pathogen of bacterial brown stripe of rice (Oryza sativa) and its ecology [in Japan]. Bull Hokuriku Nat Agri Expt Stn 38: 113-171.

9. Lyon HL (1922) A leaf disease of the Tip canes. Proc Hawaii Sugar Plant Assoc 246.

10. Agnihorti VP (1983) Diseases of sugarcane. Mohan Primlane for Oxford and IBH Publishing Co. Janapath, New Dehli, 223-229.
11. Akhtar MA, Aslam M (1986) Resistance of sugarcane to bacterial red stripe, new bacterial disease from Pakistan. Tropical Pest Management 32: 188- 119.

12. Phung CV, Man LH (2001) Effects of soil and nutrients on red stripe symptoms of rice. Planning workshop on red stripe. Los Baños (Philippines): IRRI. 21-24.

13. Somasegaran P, Hoben HJ (1994) Developing Antisera. Methods in legumerhizobium technology (Handbook for Rhizobium). Springer-verlag. New York, USA. 89-93.

14. Viswanathan R, Rao GP (2011) Disease Scenario and Management of Major Sugarcane Diseases in India. Sugarcane Technology 13: 336-353.

15. Comstock JC, Irey MS (1992) Detection of sugarcane leaf scald pathogen, Xanthomonas albilineans, using tissue blot immunoassay, ELISA and isolation techniques. Plant dis 76: 1033-1035.

16. Mughal SM, Khan MA (2006) Indirect or direct antigen coated (DAC) ELISA Lab manual of plant virology, 81-82.

17. Walcott RR, Gitaitis RD (2000) Detection of Acidovorax avenae subsp. citrulli in watermelon seed using immunomagnetic separation and the polymerase chain reaction. Plant Dis 84: 470-474

18. Song WY, Kim HM, Hwang CY, Schaad NW (2004) Detection of Acidovorax avenae subsp. avenae in Rice Seeds Using BIO-PCR. J Phytopathol 152 $667-676$.

19. Rajasulochana P, Dhamotharan R, Srinivasulu P (2008) Comparison of DACELISA and Dot-Blot-ELISA for the detection of Cucumber Mosaic and Banana Streak Viruses infecting Banana. J Am Sci 4: 18-27.

20. Garnsey SM, Permar TA, Cambra M, Henderson CT (1993) Direct tissue blots immunoassay (DTBIA) for detection of citrus tristeza virus (CTV). In: Moreno P, Dagraça JV, Timmer LW ed. Proceedings of the 12th Conference International Organization of Citrus Virologists, Riverside, United States, 39-50.

21. Rocha-Pena, MA, Lee RF (1991) Serological technique for detection of citrus tristeza virus. J Virol Methods 34: 311-331.

22. Cambra M, Gorris MT, Roman MP, Terrada E, Garnsey SM, et al. (2000) Routine detection of citrus tristeza virus by direct Immunoprinting-ELISA method using specific monoclonal and recombinant antibodies. Proceedings $14^{\text {th }}$ International Conference of the Organization of Citrus Virologists, 34-41.

23. Martín S, Alioto D, Milne RG, Guerri J, Moreno P (2002) Detection of Citrus psorosis virus in field trees by direct tissue blot immunoassay in comparison with ELISA, symptomatology, biological indexing and cross-protection tests. Plant Pathol 51: 134-141. 